\title{
Effects of Mild and Low Temperature Incubation on Heat Tolerance in Bombyx mori Embryos
}

\author{
Daisuke Matsuoka ${ }^{1}$, Katsuhiko Sakamoto ${ }^{1,2, *}$ \\ ${ }^{1}$ Biosignal Research Center, Kobe University, Kobe, Japan \\ ${ }^{2}$ Graduate School of Agricultural Science, Kobe University, Kobe, Japan \\ Email address: \\ matsuoka@people.kobe-u.ac.jp (D. Matsuoka),ksakamoto@diamond.kobe-u.ac.jp (K. Sakamoto) \\ ${ }^{*}$ Corresponding author
}

\section{To cite this article:}

Daisuke Matsuoka, Katsuhiko Sakamoto. Effects of Mild and Low Temperature Incubation on Heat Tolerance in Bombyx mori Embryos. American Journal of Entomology. Vol. 2, No. 2, 2018, pp. 6-9. doi: 10.11648/j.aje.20180202.11

Received: May 28, 2018; Accepted: June 19, 2018; Published: July 12, 2018

\begin{abstract}
Object: For ectothermic insects, thermal tolerance is one of the most essential properties for survival in ambient environments. However, the molecular mechanisms involved in thermal tolerance in the silkworm, Bombyx mori L. (Lepidoptera: Bombycidae) have not been fully elucidated. The present study investigated mechanisms that provide heat tolerance in embryos of Bombyx mori. Materials and Methods: Eggs of the bivoltine silkworm strain p50 were exposed to different temperatures, to determine the lethal threshold temperature and to assess the effects of mild and low temperature incubation on tolerance to heat shock and on embryonic protein profiles. Protein levels were measured by sodium dodecyl sulphate-polyacrylamide gel electrophoresis (SDS-PAGE). Results: When eggs were exposed to transient heat shock for one hour, the lethal threshold temperature was between $47.0^{\circ} \mathrm{C}$ and $48.0^{\circ} \mathrm{C}$. However, exposure to $40.0^{\circ} \mathrm{C}$ for four hours, substantially elevated tolerance to the threshold heat shock and simultaneously increased levels of 70 and $27 \mathrm{kDa}$ proteins in eggs, whereas exposure to $35.0^{\circ} \mathrm{C}$ did not. Exposure to $10.0^{\circ} \mathrm{C}$ for four hours lowered heat tolerance and did not alter the expression of 70 and $27 \mathrm{kDa}$ proteins. Conclusion: The present findings indicated that hardening silkworm eggs at mild temperatures increases heat tolerance in embryos. To our knowledge this is the first observation of heat hardening in silkworm embryos. These putative heat-shock proteins of 70 and 27 $\mathrm{kDa}$ might be involved in the effect of mild temperature hardening on heat tolerance. Cold stress might deprive embryos of energy reserves available for protection against heat damage. Protective mechanisms against heat and cold stress are probably different in this species. Further studies of the molecular mechanisms of heat tolerance should provide insight into the development of novel, high-yield silkworm strains in tropical environments.
\end{abstract}

Keywords: Embryo, Heat Shock Protein, Silkworm, Thermal Tolerance

\section{Introduction}

Small ectothermic insects are vulnerable to high-temperature stress [1]. Thus, thermal tolerance is one of the most essential properties for the survival of insects in ambient environments and it plays an important role in determining the geographic distribution of each species [2].

Insects, like other organisms, synthesize heat shock proteins (HSP) when exposed to elevated temperatures and other stress factors such as cold, UV light, heavy metals and organic toxic substances [3, 4]. HSPs are stress proteins that act as molecular chaperones and function in protein folding, localization and degradation in key cellular processes including protein synthesis, signalling, transcription and metabolism. They ensure survival under conditions of stress [4-6, 24, 25]. HSPs are classified into several families such as HSP90, HSP70, HSP60 and small heat shock proteins (molecular weight range, $12-43 \mathrm{kDa}$ ) according to molecular weight and sequence similarity [5-7].

Silkworms (Bombyx mori L.) are beneficial insects of economic importance. Tropical multivoltine races resist high temperatures better than temperate bi- or univoltine races, whereas, cocoon and silk yield, as well as the quality of silk yarn generated from tropical races are inferior to those of temperate races [8-10]. Therefore, heat-resistant and high-yield strains that can adapt to tropical climates are in demand by the silk market and silk farmers. Studies of heat shock responses at the various developmental stages of 
different silkworm strains have often focused on HSP expression [9-12]. However, the molecular mechanisms involved in thermal tolerance in Bombyx mori have not been fully elucidated and few studies have investigated heat shock responses in silkworm embryos at the molecular level [13].

The present study aimed to determine the embryonic mechanisms involved in heat tolerance in the silkworm. The present study identified the lethal threshold temperature of transient heat shock, and then assessed the effects of mild and low temperatures on tolerance to heat shock and on embryonic protein profiles.

\section{Materials and Methods}

\subsection{Animals}

The National Bio-Resource Project (NBRP) of the Ministry of Education, Science, Sports and Culture of Japan (http://www.shigen.nig.ac.jp/silkwormbase/index.jsp)

provided diapause eggs of the bivoltine silkworm strain, p50. Eggs were incubated essentially at $25^{\circ} \mathrm{C}$ and exposed to different temperatures in a relative humidity of $80 \% \pm 10 \%$ under a daily $12 \mathrm{~h}$ light- $12 \mathrm{~h}$ dark cycle.

\subsection{Thermal Treatment}

Eggs (three-day-old embryos) were incubated for one hour at $48.0^{\circ} \mathrm{C}, 47.0^{\circ} \mathrm{C}, 46.0^{\circ} \mathrm{C}, 44.0^{\circ} \mathrm{C}$ or $25.0^{\circ} \mathrm{C}$ (control) to determine the lethal threshold temperature.

The present study also examined the effects of incubating eggs for four hours at $40.0^{\circ} \mathrm{C}, 35.0^{\circ} \mathrm{C}, 25.0^{\circ} \mathrm{C}$ (control) or $10.0^{\circ} \mathrm{C}$ followed by one hour of recovery at $25^{\circ} \mathrm{C}$. The eggs were then incubated for one hour at high temperatures of $47.2^{\circ} \mathrm{C}$ and $47.0^{\circ} \mathrm{C}$, and control eggs were incubated at $25.0^{\circ} \mathrm{C}$.

Hatched larvae were counted for two weeks after starting the incubation of eggs, to determine the effects of various temperatures on embryonic survival. Unhatched eggs were judged as dead. Survival was defined as the ratio (\%) of hatched larvae in each experimental group.

\subsection{Statistical Analysis}

Survival rates are expressed as the means with standard deviations (SD) of four independent groups of $90-137$ individuals per group. Mean values were statistically analyzed using one-way analyses of variance (ANOVA) followed by Tukey-Kramer tests. $P<0.05$ was considered to represent significance.

\subsection{Extraction and Analysis of Egg Protein}

Sample eggs (three-day-old embryos) were collected, immediately frozen in liquid nitrogen and stored at $-80^{\circ} \mathrm{C}$. Frozen eggs were ground in liquid nitrogen and homogenized in phosphate-buffered saline $(100 \mu \mathrm{g}$ eggs $/ \mathrm{mL})$ for protein extraction. Homogenates were separated by centrifugation at $13,000 \mathrm{~g}$ for $20 \mathrm{~min}$ at $4^{\circ} \mathrm{C}$, and supernatants were resolved by sodium dodecyl sulphate-polyacrylamide gel electrophoresis (SDS-PAGE) [14].

\section{Results}

\subsection{Thermal Treatment}

Heat shock for one hour at $44.0^{\circ} \mathrm{C}$ and $46.0^{\circ} \mathrm{C}$ did not significantly affect embryonic survival rates $(93.3 \%$ and $87.7 \%$, respectively), but survivability at $47.0^{\circ} \mathrm{C}$ and $48.0^{\circ} \mathrm{C}$ dropped to $60.7 \%$ and $0 \%$, respectively (Figure 1 ).

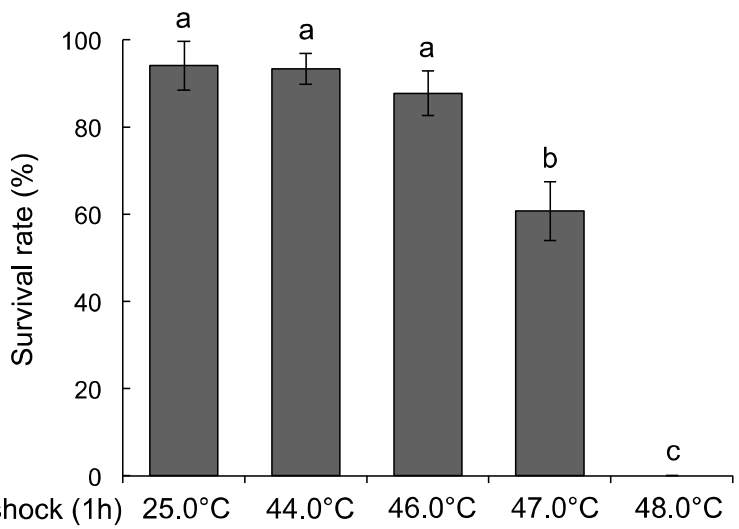

Heat shock (1h) $25.0^{\circ} \mathrm{C} \quad 44.0^{\circ} \mathrm{C} \quad 46.0^{\circ} \mathrm{C} \quad 47.0^{\circ} \mathrm{C} \quad 48.0^{\circ} \mathrm{C}$

Figure 1. Effects of transient heat shock on survival rate of Bombyx mori embryos. Eggs were exposed to temperatures of $48.0^{\circ} \mathrm{C}, 47.0^{\circ} \mathrm{C}, 46.0^{\circ} \mathrm{C}$, $44.0^{\circ} \mathrm{C}$ or $25.0^{\circ} \mathrm{C}$ (control) for one hour. Survival rates of four independent groups are expressed as means with standard deviations. Superscript letters indicate significantly different survival rates among experimental groups (ANOVA and Tukey-Kramer test, $P<0.05$ ).

The survival rate after exposure to heat shock at $47.2^{\circ} \mathrm{C}$ dropped to $7.8 \%$ (Figure $2 \mathrm{a}$ ). In contrast, incubation for four hours at $40.0^{\circ} \mathrm{C}$, but not at $35.0^{\circ} \mathrm{C}$, increased the survival rate of eggs that were subsequently shocked at $47.2^{\circ} \mathrm{C}$, to $93.7 \%$, which was as high as that of controls maintained at $25.0^{\circ} \mathrm{C}$ (Figure 2a). On the contrary, incubation at $10.0^{\circ} \mathrm{C}$ lowered the survival rate from $67.4 \%$ to $3.4 \%$ among eggs that were exposed to heat shock at $47.0^{\circ} \mathrm{C}$ (Figure $2 b$ ). However, eggs incubated at $10.0^{\circ} \mathrm{C}$ hatched normally $(98.8 \%)$ after heat shock at $25.0^{\circ} \mathrm{C}$ (Figure $2 \mathrm{~b}$ ).

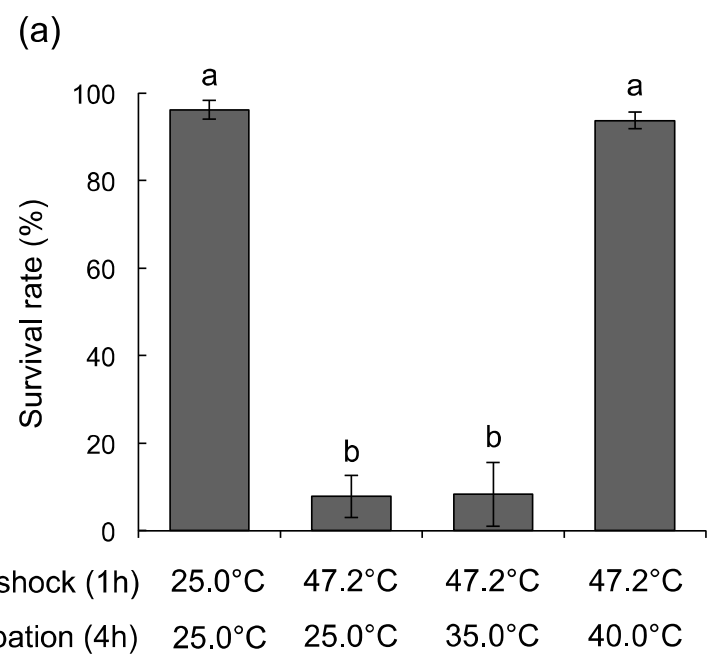


(b)

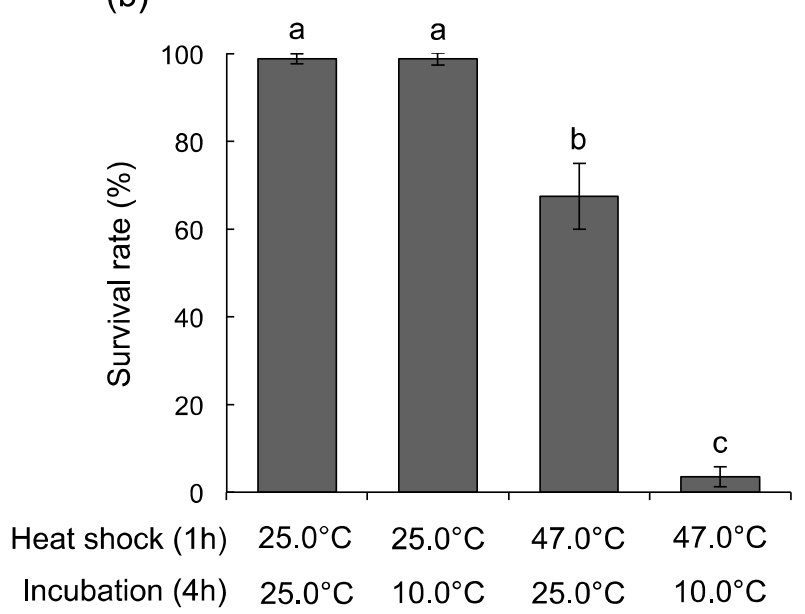

Figure 2. Effects of mild and low temperature incubation on heat shock tolerance in Bombyx mori embryos. (a) Mild temperature: Eggs were incubated for four hours at $40.0^{\circ} \mathrm{C}$ or $35.0^{\circ} \mathrm{C}$, recovered at $25^{\circ} \mathrm{C}$ for one hour, then heat-shocked for one hour at $47.2^{\circ} \mathrm{C}$. Control eggs were incubated at $25.0^{\circ} \mathrm{C}$ throughout the experiment. (b) Low temperature: Eggs were incubated for four hours at $10.0^{\circ} \mathrm{C}$, recovered at $25^{\circ} \mathrm{C}$ for one hour, then heat-shocked for one hour at $47.0^{\circ} \mathrm{C}$. Control eggs were incubated at $25.0^{\circ} \mathrm{C}$ throughout the experiment. Survival rates of four independent groups are expressed as means with standard deviations. Superscript letters indicate significantly different survival rates among experimental groups (ANOVA and Tukey-Kramer test, $P<0.05$ ).

\subsection{Protein Profiles in Eggs}

The amounts of 70 and $27 \mathrm{kDa}$ proteins extracted from eggs and resolved by SDS-PAGE increased after incubation for four hours at $40.0^{\circ} \mathrm{C}$, but not at $35.0^{\circ} \mathrm{C}$ (Figure 3a). Incubation at $10.0^{\circ} \mathrm{C}$ did not alter protein profiles (Figure $3 \mathrm{~b}$ ).

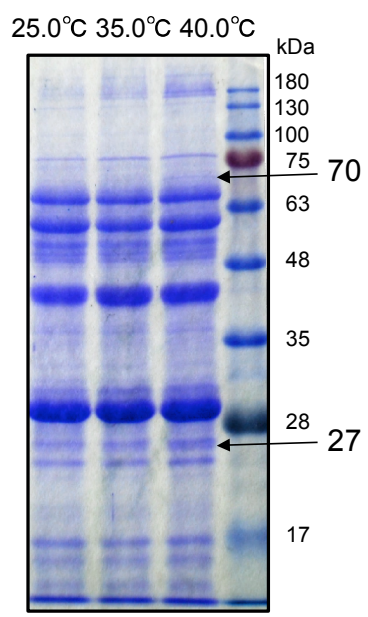

(a)

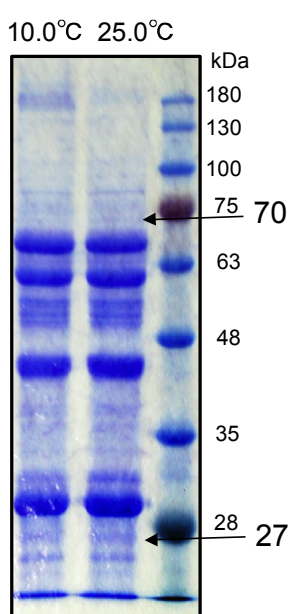

(b)
Figure 3. Protein profiles of Bombyx mori embryos incubated at mild and low temperatures. (a) Mild temperature: Eggs were incubated for four hours at $40.0^{\circ} \mathrm{C}, 35.0^{\circ} \mathrm{C}$ or $25.0^{\circ} \mathrm{C}$ (control) followed by one hour of recovery at $25^{\circ} \mathrm{C}$. (b) Low temperature: Eggs were incubated for four hours at $10.0^{\circ} \mathrm{C}$ or $25.0^{\circ} \mathrm{C}$ (control) followed by one hour of recovery at $25^{\circ} \mathrm{C}$. Total protein extracts (two eggs/lane) were separated by SDS-PAGE on $10 \%$ (a) or $12.5 \%$ (b) polyacrylamide gels and visualised by Coomassie Brilliant Blue staining. Arrows indicate 70 and $27 \mathrm{kDa}$ proteins.

\section{Discussion}

The present study initially determined the impact of heat shock for one hour on embryos of the silkworm strain p50. The lethal threshold temperature was between $47.0^{\circ} \mathrm{C}$ and $48.0^{\circ} \mathrm{C}$. In fact, heat shock at $47.0^{\circ} \mathrm{C}$ and $47.2^{\circ} \mathrm{C}$ decreased survival rates to $60.7 \%-67.4 \%$, and $7.8 \%$, respectively. These threshold temperatures were similar to the range of $43^{\circ} \mathrm{C}-48^{\circ} \mathrm{C}$ that has been reported as threshold or sublethal temperatures for other strains of silkworm eggs [11, 13, 15], although they cannot be strictly compared due to differences in breeding and experimental procedures.

The present study then examined the effects of exposing silkworm eggs to mild and low temperatures on embryonic tolerance of lethal threshold temperatures. Mild temperature hardening obviously improved heat tolerance in silkworm embryos. Although this phenomenon of heat hardening is common among insects $[4,16,17]$, to our knowledge this is the first description of heat hardening in silkworm embryos. In contrast, incubating eggs at low temperatures decreased heat tolerance. A cross-protection effect that cold hardening increases heat resistance has been observed in Drosophila melanogaster [16]. However, protective mechanisms for heat and cold stress appeared to differ in silkworms, as in the pea leafminer, Liriomyza huidobrensis [17].

Protein separation by SDS-PAGE revealed that incubating eggs at mild temperatures increased the amounts of 70 and 27 kDa proteins that might correspond to HSP70 and HSP27, respectively. Several studies have shown that silkworm larvae under heat stress produce HSP70 and near 27-kDa (26, 28 and $29 \mathrm{kDa}$ ) proteins [10-11, 18]. The main Drosophila HSP that functions in thermal tolerance is inducible HSP70 [4, 19, 20], and HSP27 is also involved in resistance to heat stress [21]. The gene expression of HSP70 and HSP20 (but not HSP27) is upregulated by mild temperature hardening that increases heat tolerance in Liriomyza huidobrensis [17]. Taken together with these results, the present findings suggest that 70 and $27 \mathrm{kDa}$ proteins are involved in mild temperature hardening that helps silkworm embryos to tolerate heat.

On the other hand, incubating silkworm eggs at low temperatures did not affect 70 or $27 \mathrm{kDa}$ protein expression, and tolerance to elevated temperatures was decreased. Since HSP synthesis consumes energy [22,23], embryos might have evoked a response for cold resistance and used energy reserves that were destined for heat resistance. More detailed studies are required to clarify how 70 and $27 \mathrm{kDa}$ proteins are involved in the protective mechanisms of heat tolerance in silkworm embryos.

\section{Conclusion}

The present findings indicated that hardening silkworm eggs at mild temperatures increases heat tolerance in embryos. Although this phenomenon of heat hardening is common among insects, to our knowledge this is the first description of heat hardening in silkworm embryos. In addition, the present study suggested that the 70- and 27-kDa proteins in silkworm 
embryos generate tolerance against elevated temperatures. These proteins might correspond to HSP70 and HSP27, respectively, because several studies have shown that HSP70 and HSP27 are involved in resistance to heat stress in other species. The present study also indicated that protective mechanisms against heat and cold stress differ in silkworms. A cross-protection effect that cold hardening increases heat resistance has been observed in Drosophila melanogaster. Protective mechanisms for thermal stress appeared to differ among species. Further studies of protective mechanisms of heat tolerance should provide insight into the development of novel high-yield silkworm strains that will thrive in tropical climates.

\section{References}

[1] Worner, S. P. (1988). Ecoclimatic assessment of potential establishment of exotic pests. Journal of Economic Entomology, 81: 973-983.

[2] García-Robledo, C., Kuprewicz, E. K., Staines, C. L., Erwin, T. L. and Kress, W. J. (2016). Limited tolerance by insects to high temperatures across tropical elevational gradients and the implications of global warming for extinction. Proceedings of the National Academy of Sciences of the United States of America, 113: 3680-685.

[3] Zhao, L. and Jones, W. A. (2012). Expression of heat shock protein genes in insect stress responses. Invertebrate Survival Journal, 9: 93-101.

[4] King, A. M. and MacRae T. H. (2015). Insect heat shock proteins during stress and diapause. Annual Review of Entomology, 60: 59-75.

[5] Feder, M. E. and Hofmann, G. E. (1999). Heat-shock proteins, molecular chaperones, and the stress response: evolutioinary and ecological physiology. Annual Review of Physiology, 61: 243-282.

[6] Sørensen, J. G., Kristensen, T. N. and Loeschcke, V. (2003). The evolutionary and ecological role of heat shock proteins. Ecological Letters, 6: 1025-1037.

[7] Kim, K. K., Kim, R. and Kim, S. H. (1998). Crystal structure of a small heat-shock protein. Nature, 394: 595-599.

[8] Rahmathulla, V. K. (2012). Management of climatic factors for successful silkworm (Bombyx mori L.) crop and higher silk production: A review. Psyche, 2012: 121234.

[9] Vasudha, B. C., Aparna, H. S. and Manjunatha, H. B. (2006). Impact of heat shock on heat shock proteins expression, biological and commercial traits of Bombyx mori. Insect Science, 13: 243-250.

[10] Manjunatha, H. B., Rajesh, R. K. and Aparna, H. S. (2010). Silkworm thermal biology: A review of heat shock response, heat shock proteins and heat acclimation in the domesticated silkworm, Bombyx mori. Journal of Insect Science, 10: 1-16.

[11] Joy, O. and Gopinathan, K. T. P. (1995). Heat shock response in mulberry silkworm races with different thermotolerances. Journal of Biosciences, 20: 499-513.
[12] Malik, F. A. and Reddy, Y. S. (2009). Racial features in the heat tolerance limits in the silkworm, Bombyx mori. Acta Entomologica Sinica, 52: 478-486.

[13] Manjunatha, H. B., Zamood, A., Vasudha, B. C. and Aparna, H S. (2005). Heat shock response and analysis of egg proteins in new bivoltine strains of Bombyx mori. Sericologia, 45: 403-408.

[14] Weber, K. and Osborn, M. (1969). The reliability of molecular weight determination by dodecyl sulfate-polyacrylamide gel electrophoresis. Journal of Biological Chemistry, 244: 4406-4412.

[15] Rat'kin, E. V. (1974). Variability of silkworm (Bombyx mori L.) eggs in capacity for thermal parthenogenesis and heat resistance. Communication I. Familial variability and connection between heat resistance of embryos in early and late stages of development. The Soviet Journal of developmental biology, 4: 454-459.

[16] Sejerkilde, M., Sørensen, J. G. and Loeschcke, V. (2003). Effects of cold- and heat hardening on thermal resistance in Drosophila melanogaster. Journal of Insect Physiology, 49: 719-726.

[17] Huang, L. H., Chen, B. and Kang, L. (2007). Impact of mild temperature hardening on thermotolerance, fecundity, and Hsp gene expression in Liriomyza huidobrensis. Journal of Insect Physiology, 53: 1199-1205.

[18] Moghaddam, S. H. H., Du, X., Li, J., Cao, J., Zhong, B. and Chen, Y. Y. (2008). Proteome Analysis on differentially expressed proteins of the fat body of two silkworm breeds, Bombyx mori, exposed to heat shock exposure. Biotechnology and Bioprocess Engineering, 13: 624-631.

[19] Bettencourt, B. R., Feder, M. E. and Cavicchi, S. (1999). Experimental evolution of HSP70 expression and thermotolerance in Drosophila melanogaster. Evolution, 53: 484-492.

[20] Dahlgaard, J., Loeschcke, V., Michalak, P. and Justesen, J. (1998). Induced thermotolerance and associated expression of the heat-shock protein HSP70 in adult Drosophila melanogaster. Functional Ecology, 12: 786-793.

[21] Wang, H. D., Kazemi-Esfarjani, P. and Benzer, S. (2004). Multiple-stress analysis for isolation of Drosophila longevity genes. Proceedings of the National Academy of Sciences of the United States of America, 101: 12610-12615.

[22] Hoffmann, A. A. (1995). Acclimation: increasing survival at a cost. Trends in Ecology and Evolution, 10: 1-2.

[23] Koehn, R. K. and Bayne, B. L. (1989). Towards a physiological and genetical understanding of the energetics of the stress response. Biological Journal of the Linnean Society (London), 37: 157-171.

[24] Rodríguez-Iturbe, B. and Johnson, R. J. (2018). Heat shock proteins and cardiovascular disease. Physiology International, 105: 19-37.

[25] Penke, B., Bogár, F., Crul, T., Sántha, M., Tóth, M. E. and Vígh, L. (2018). Heat shock proteins and autophagy pathways in neuroprotection: from molecular bases to pharmacological interventions. International Journal of Molecular Science, 19: 325. 